\title{
COVID-19: Determining the perception, anxiety, and behavior change during a pandemic outbreak in Bangladesh.
}

Rezaul Karim Ripon ( $\nabla$ riponrezaul5@gmail.com )

Jahngirnagar University https://orcid.org/0000-0003-4310-5382

Sadia sultana Mim

Jahangirnagar University

\section{C.L. C.L. Mulder}

Epidemiological and Social Psychiatric Research institute

Article

Keywords: COVID-19, perception, anxiety, behavioral change

Posted Date: October 6th, 2020

DOl: https://doi.org/10.21203/rs.3.rs-83106/v1

License: (9) (7) This work is licensed under a Creative Commons Attribution 4.0 International License. Read Full License 


\section{Abstract}

Background: With the novel coronavirus (COVID-19) outbreak worldwide, many people were advised to maintain specific precautionary measures for not catching the disease. The objectives of this study were to assess the perception, anxiety and behavior change of a population in Bangladesh during the COVID-19 outbreak.

Methods: A total of 6400 individuals comprised the population of this study. Subjects were respondents to an online questionnaire that was administered through social media. The questionnaire included items on personal information; nine items about participants' recent behaviors', 42 items were used to assess how people perceived coronavirus outbreaks. Six out of the 42 items assessed whether participants believed certain actions can reduce their risk of catching corona virus. Anxiety was assessed using a six-item version of the list of valid state-specific concerns [The State-Trait Anxiety Inventory (STAI)] scale. Data were collected and analyzed by regression analyses on a SPSS program.

Results: $60 \%$ of participants $(n=3840$ ) reported performing change any avoidance behavior (social event or crowd place, mass

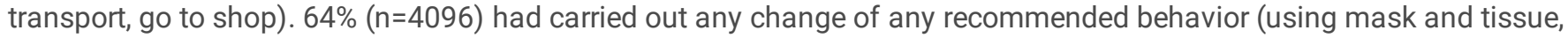
disinfecting used things, washing hands, maintaining social distance, maintaining isolation). $0.3 \%(n=1920)$ scored 18 or more on the anxiety scale, suggesting high anxiety. The strongest predictor of behavior change (recommended and avoidance) was "having a chronic illness". Participants who had carried out one or more recommended behaviors' had significantly higher levels of "trust in government" odds ratio: $2.33,95 \% \mathrm{Cl}$ : 2.07-2.61. Similarly, participants who had carried out one or more avoidance behaviors also had significantly higher levels of "trust in government" $(1.90,1.72-2.10)$.

Conclusion: If the government and health care workers become aware of such findings, measures and policies can be taken to alleviate the resultant sufferings.

\section{Introduction}

In January 2020, the World Health Organization (WHO) declared that the novel coronavirus (COVID-19) is the $6^{\text {th }}$ public health emergency of an international proportion (World Health Organization, 2020). COVID-19 was officially declared as a pandemic by WHO in March 2020 (World Health organization, 2020). In April 2020, the presence of COVID-19 was confirmed in 210 countries or territories (World Health Organization, 2020). In Bangladesh the first cluster of Covid-19 was seen in Tolarbag, Dhaka during March: a man who came from Italy and his two family members (Institute of Epidemiology, Disease Control and Research, 2020). To date, the scientific community has described the clinical course of COVID-19, is counting the cases, and is trying to develop a vaccine (Dong et al., 2020). However, COVID-19 has a very high infection rate and relatively high mortality rate (e.g., $3.6 \%$ and $1.5 \%$ in China and abroad). COVID-19 has a mortality rate of about $2.2 \%$ in Bangladesh, much lower than the other two corona virus epidemics of the 21th century (Institute of Epidemiology, Disease Control and Research, 2020). The source of the infection is probably from zoonotic or environmental contact. Human-to-human transmission is responsible for most of the infections in Bangladesh.

Without pharmaceutical interventions (e.g., vaccine), change in behaviors; perceptions are only methods to protect from coronavirus. With the novel coronavirus (COVID-19) outbreak worldwide, many people were instructed to change their behavior as a precautionary measure for not catching the disease. Some people follow these precautionary measures as recommended and some had to deny measure as precautionary known avoidance. Recommended behaviors are like that using mask and tissue, disinfecting used things, washing hands, maintaining social distance, maintaining isolation and avoidance behavior are like that social event or crowd place, mass transport, and going shopping. Behavioral (recommended and avoidance) drivers involve knowledge or skills, social norms or physical resources and aspirations or passions or habits. The irrational message of policy, information and messaging leads to psycho-social behavioral consequences. It can increase anxiety, widen social deprivation, lead to social isolation. Behavioral changes are related to, but not limited to, COVID-19. Almost everyone is a little worried about this change. Anxiety is important to affect the success or failure of each step of the alert system. A sequence of anxieties occurs; High levels of anxiety are characterized by catastrophic misinterpretations of behavioral changes, and this misconception about coronavirus can be detrimental (Asmundson \& Taylor, 2020). The COVID-19 pandemic causes panic and mental health problems for the public (Bao et al., 2020; Xu et al., 2020).Psychosocial behavior consequences of COVID-19 can be fatal [Wanjie Tanga et al., (2020)] for public. It is estimated that $30-50 \%$ of the population affected by a disaster suffers from various psychological crises (Dutheil et al., 2020). Notable psychiatrists include a variety of delirium, psychosis, and even suicide from anxiety, depression, panic attacks, somatic 
symptoms, and PTSD. Also, persons may experience guilt, shame or stigma. High levels of psychological distress among those who had endured prolonged periods of quarantine time would likely be associated with increased prognosis of PTSD and related to depressive symptoms (Ho et al., 2020). Even due to anxiety, stigma and depression, suicidal cases happened in Bangladesh (Dhaka Tribune, 2020) .Managing patients with severe psychiatric disorders who had suspected or confirmed COVID-19 had created a major logistical challenge (Xiang, et al., 2020). Anxiety is like the second tsunami of the SARS-Cov-2 pandemic. The goal of avoiding inequality is to make everyone equally aware. Information and messages received from multiple channels are immutable and thus complicate the coronavirus alert system (The British Psychological Society, 2020). The aim of our study is to assess behavior change and understanding perception and anxiety level. Therefore, during COVID-19 outbreak, the adjustment of public health behavior, knowledge and risk perception is an important topic for research.

\section{Method}

\subsection{Setting: The coronavirus outbreak in Bangladesh}

According to media reports in Bangladesh, the corona virus outbreak started on March 8,2020 , and is ongoing. Up to July 20, the day our data collection ended, 339332 people in Bangladesh were confirmed to be COVID-19 and all schools were closed as a precautionary measure (Institute of Epidemiology, Disease Control and Research, 2020). At this time the government started a big advertising campaign to give information and advice to the public, including information on the nature of the virus, what the government did to create the pandemic, and what individuals could do to protect themselves and others.

During the outbreak of COVID-19 and until June 1, 2020, 304330 people were instructed to remain in mandatory quarantine and not to leave the quarantine place in Bangladesh (World Health Organization, 2020). They are told to wash their hands frequently, and to wear masks when they felt any difficulty with breathing. In addition, instructions were that if individuals experience shortness of breath, chest pain or pressure, loss of speech or movement, they should seek immediate medical attention. If the symptoms were mild, they were instructed to manage it at home (self-quarantine).

Participants:

Bangladeshi citizens who were 18 years of age and above were eligible participants in this study. Participation in the study was voluntary - as the survey instrument was administered through social media, Facebook and Linkedln network. Some respondents who did not complete the $10^{\text {th }}$ grade of schooling, or unemployed were excluded. A total of 6000 included individuals responded to the administered questionnaire. It was conducted in the Bangla Language and was available online between the $10^{\text {th }}$ to the $29^{\text {th }}$ of May 2020. It was estimated that the questionnaire takes more than 15 min to complete. Questions were to collect demographic information of participants, were related to quarantine knowledge,perceptions, and to assess the psychological effects. Data were collected from $1^{\text {st }}$ July to 20 July and the study is approved (ref: PHI/2020/2393).

Assessments

The questionnaire we used was made by experts from a questionnaire panel in Bangladesh using WHO, CDC and national COVID-19 guidelines. The administered survey was in a form of a questionnaire that comprised 42 questions. Nine items about participants' recent behaviors', six items assessed whether participants believed certain actions can reduce their risk of catching corona virus. 21 items were used to assess the perception of coronavirus and anxiety was assessed using a six-item version of the list of valid statespecific concerns STAI scale.

\subsection{Behavior:}

Nine items about participants recent behaviors'. Three related to avoiding behavior not for catching coronavirus (social event or crowd place, mass transport, go to shop) as precaution measures. Recommended (Using mask and tissue, disinfect used things, wash hand, maintaining social distance, maintaining isolation) related to the six activities as precautions measures. The answers of questions were marked "I had this for the last four days.......due to coronavirus". Table 1 lists the complete item words. The answer categories were "yes or no".

3.3. Perceived efficacy of behaviors':

Page $3 / 12$ 
Six items assessed whether participants believed that certain actions reduced their risk of catching corona virus. With possible response options strongly agreed (scored as 1), the trend to agree (2), neither agree nor disagree (3), the trend to disagree (4) and strongly disagree (5) [Table: 2].

\subsection{Anxiety}

Anxiety was assessed using a six-item version of the list of valid state-specific concerns STAl scale. (Marteau \& Bekker, 1992)]. The proposal stated that respondents should respond to how they have been feeling about the corona virus for the past four days. This scale provides scores between 6 (lowest Anxiety) and 24 (highest Anxiety). We categorized 12 or more scorers as anxious about coronavirus and classified those who scored 18 or higher as high anxious about coronavirus (Uzun et al., 2008).

\subsection{Perceptions}

21 items were used to assess how people perceived coronavirus outbreaks. The perception items were marked as statements, with the response options strongly agree (1) to strongly disagree (5). Exploratory factor analysis using principal axis factoring and varimax rotation suggested that nine factors were present in the data. By checking the content of the items loading more than 0.6 on a specific factor, the overarching concept could easily be described. Five factors were used in the formation of the scale (box). For the remaining four factors with a Cronbach alpha score being less than 0.6 were excluded as they couldn't well fit with the analysis.

Perception scales used in the analyses, with examples of items 


\begin{tabular}{|c|c|c|}
\hline $\begin{array}{l}\text { Factors } \\
\text { Prevalence }(\% \\
\text { \& }(X \pm S D)\end{array}$ & $\begin{array}{l}\text { Cronbach's } \\
\text { a }\end{array}$ & Items/Statements \\
\hline $\begin{array}{l}\text { Trust in the } \\
\text { authority's } \\
13 \% \\
3.2 \pm .12\end{array}$ & .88 & $\begin{array}{l}\text { In general, I think the authorities are acting in the public's best interest in dealing with the corona } \\
\text { virus outbreak. } \\
\text { A surgical mask prevents healthy people from contracting coronavirus. } \\
\text { Hand washing and disinfection are a key element in preventing infection. } \\
\text { Government instruction is enough for prevent coronavirus. } \\
\text { Government try to best to prevent coronavirus. }\end{array}$ \\
\hline $\begin{array}{l}\text { Likelihood of } \\
\text { infection } \\
35 \% \\
2.5 \pm 1.1\end{array}$ & .84 & $\begin{array}{l}\text { I believe there is currently a high risk of catching corona virus in the shops I go to. } \\
\text { In case of symptoms such as cough or fever, people should go to the emergency department. } \\
\text { People can contract coronavirus from their dogs or cats. } \\
\text { Parcels from China or other countries with a high infection rate can transmit coronavirus. } \\
\text { Coronavirus is spread by contact with the bus or the subway handles. }\end{array}$ \\
\hline $\begin{array}{l}\text { Severity of } \\
\text { illness } \\
21 \% \\
1.8 \pm .1\end{array}$ & .74 & $\begin{array}{l}\text { I think that if I corona virus will have major consequences for my life. } \\
\text { Coronavirus can be transmitted from person to person. } \\
\text { If one infected by coronavirus, he or she will die. } \\
\text { To prevent from catch coronavirus, one can change his or her nutritional habits for strong } \\
\text { immunity. }\end{array}$ \\
\hline $\begin{array}{l}\text { Exaggeration } \\
\text { of the risk } \\
12 \% \\
.7 \pm .01\end{array}$ & .85 & $\begin{array}{l}\text { I think that the media have over-exaggerated the risks of catching coronavirus. } \\
\text { Antibiotics can help preventing new coronavirus infections. }\end{array}$ \\
\hline $\begin{array}{l}\text { Timeline for } \\
\text { the outbreak } \\
19 \% \\
.8 \pm .1\end{array}$ & .81 & $\begin{array}{l}\text { In my opinion, this coronavirus outbreak is going to continue for a long time. } \\
\text { A person suspected of having contracted coronavirus, or with symptoms such as coughing or } \\
\text { sneezing, should wear the mask in the presence of other people in these days. }\end{array}$ \\
\hline
\end{tabular}

3.6. Personal and other variables: Personal variables consisted of sex, age, income, educational level, region and the presence of any chronic somatic illness (Diabetes, hypertension etc.)

3.6. Analysis: We calculated the prevalence of two primary outcomes; whether the participant had engaged in any of the three behaviors' avoidance and whether the participant had engaged in any of the six recommended behaviors' (table 1). Binary logistic regressions were used to calculate the univariate associations between personal characteristics, perception variable and primary outcomes. We used t-tests to compare between anxiety levels and primary outcomes. The analysis occurs in a SPSS program.

\section{Results}

$64 \%(n=4096)$ respondents reported engaging in one or more of recommended behavior, whereas $60 \%(n=3840)$ said that they had carried out one or more of the three avoidance behaviors'. [ Table:1]. Change in any recommended behaviors highly prevalence among female $(n=2176,32 \%)$; age 30 to 50 years $(n=1408,21.02 \%)$; income 20000 to 50000 in Bangladeshi currency ( $n=1664$, $24.84 \%)$; having no chronic diseases $(n=2048,30.57 \%)$; village dwellers $(n=2048,30.57 \%)$; education level more than grade $12(n=$ $2560,38.21 \%)$. Thus way change in avoidance behaviors among female $(n=2304,34.39 \%)$; age 30 to $50(n=2048,30.57 \%)$; income 20000 to 50000in Bangladeshi currency ( $n=1408,21.02 \%)$; having no chronic disease $(n=2304,34.3 \%)$; city dwellers $(n=2176$, $32.48 \%)$; education level more than grade $12(n=2304,34.3 \%)$ [Table: 3]. In perceived efficacy of various behavioral responses 
regarding to coronavirus questionnaire: $1664(26 \%)$ respondents was strongly agree in the statement "Reducing the number of people you meet over a day"; 3200(50\%) in "avoiding transport"; $1920(30 \%)$ in "Cleaning or disinfecting things you might touch" ; and 2560(40\%) in "Wearing a face mask when out in public". Thus 2432(38\%) respondents strongly disagree in the statement "Avoiding hospitals or general practices" and 2176 (34\%) in "Washing your hands regularly with soap and water" [Table: 2]. In STAI scale, $32 \%(n=1920)$ respondents scored 18 or more, suggesting high anxiety about COVID-19. The strongest predictor of behavior change with participants from "having chronic illness" being more likely to make recommended changes (odds ratio 2.6, 95\%: 2.42.9) and change in avoidance behaviors' (2.02, 1.81-2.3). Participants who had carried out one or more recommended behaviors' had significantly higher levels of "trust in government" (odds ratio $2.3,95 \% \mathrm{Cl}$ : 2.1-2.6). Similarly, participants who had carried out one or more avoidance behaviors' had significantly higher levels of "trust in government" (1.9, 1.7-2.1) [Table: 4].

\subsection{Association between demographic variables and behavior}

Table 3 shows the associations between personal variables and behavior. The largest effects were for participants having a chronic disease, adopting recommended behaviors' (odds ratio 2.6, 95\% Cl: 2.4-2.9) and avoidance behaviors' (2.02, 1.8-2.3). Further analyses showed that having a chronic disease remained a significant predictor for recommended behaviors' $(3.4,3.1-3.8)$ and avoidance behaviors' (1.2, 1.75-2.2) even after adjusting for age, sex, education, income, and region.

\subsection{Association between anxiety and behavior}

In STAI scale, 32\% ( $n=1920)$ respondents scored 18 or more, suggesting high anxiety and $82 \%(n=5248)$ scored 12 or more, suggesting anxiety about COVID-19. Participants who had carried out one or more recommended behaviors' had significantly higher levels of anxiety (mean difference $14.48,95 \% \mathrm{Cl}$ : 14.38-14.58, $\mathrm{t}=290.6, \mathrm{df}=3711, \mathrm{P}<0.001$ ). Similarly, participants who had carried out one or more avoidance behaviors' had significantly higher levels of anxiety $(15.09,14.98-315.20, t=280.8, d f=4095, P<0.001)$.

\subsection{Association between perceptions and behavior}

Table 4 shows the mean scores for the perception factors and the univariate and multivariate associations between perceptions and behavior change. The factors also remain significant after adjusting for demographic variables (age, sex, education, income, and region). Participants who had carried out one or more recommended behaviors' had significantly higher levels of trust in government (odd ratio 2.3, 95\% Cl: 2.1-2.6, P<0.001). Similarly, participants who had carried out one or more avoidance behaviors' had significantly higher levels of trust in government $(1.9,1.7-2.1, \mathrm{P}<0.001)$. Further analyses showed that trust in government remained a significant predictor for avoidance behaviors' $(1.637,1.401-1.913)$ and recommended behaviors' $(1.901,1.722-2.097)$ even after adjusting for age, sex, education, income, having chronic diseases and region.

\section{Discussion}

The Spanish flu, the Asiatic flu, the SARS, the Swine flu, the Ebola affected people worldwide. They affect people's behavior and psychology. People who are faced with potential pandemic threat, are prone to develop recommended and avoidant behaviors to protect themselves (Zhou et al., 2020). Behavioral sciences seek to understand psychological, biological, social, and environmental factors that may influence behavior development in infection control (West et al., 2020)COVID-19 not only challenges for change in behavior, but also affects people's mental health (emotions and cognition) (Zhou et al., 2020). Mental health serves also a crucial role in combating a pandemic with effecting the world environment for protecting viral outbreaks. Psychosocial effects for these epidemics or pandemics included recommended or avoidant behaviors, emotional distress and protective responses like COVID-19 (Zhaia \& Du, 2020 ; D et al., 2020) COVID-19 has adverse effects on brain, that can influence for economic downturn, quarantine, social isolation, unemployment, homelessness, insomnia , indignation, sensitivity to social risks , life dissatisfaction , phobias , behavior change (avoidance, recommended behavior) and physical symptoms (D et al., 2020) , perceptions factors. Although there is an association with suicide, anxiety, emotional distress, risk of post-traumatic stress disorder and depression. COVID-19 treatment (e.g., vaccine), local outbreak, hand hygiene, wearing a mask has an association with psychology (Wang et al., 2020). Knowledge can influence the perceptions of the people although for COVID-19 it's unclear (Bhagavathula et al., 2020). In Pakistan, corona virus has reduced shop visits by $88.8 \%$; reduced physical contact by $86.5 \% ; 74.5 \%$ inspect healthcare facilities; $84.5 \%$ cancelled plans; and $87 \%$ washed their hands often (Balkhi et al., 2020). But in Bangladesh, reduced shop visits by $30 \%$; reduced physical contact by $54 \%$; $48 \%$ cancelled plans; and $28 \%$ washed their hands often. That's why Pakistan COVID-19 situation is better positioned than 
Bangladesh. COVID-19 creates psychological burden (social and broader behavior). Aligning behaviors does not have long-term effects (Bavel et al., 2020).

The prevalence of anxiety in Pakistan was between $62.5 \%$ and avoidance behavior $(P=0.04)$ as a result of social media use among those under 35 years of age (Bavel et al., 2020). Italy, China, Singapore; Less anxiety was associated with higher efficacy (confidence in the ability to protect oneself from infection). High-level of anxiety were associated with higher scores for prejudice and casualties, and the traditional media as a reliable source of information for both Singapore and Italy (Lim et al., 2020). But in Bangladesh the prevalence of anxiety was $82 \%$. The level of anxiety and changes in behavioral responses to anxiety may be influenced by the information provided. Hand washing education and information are important but not enough to change habits. Messages that draw attention, facilitate consent, and mention abomination increase the use of alcoholic hand sanitizers. Interventions to touch appearance need to change the physical and social environment to change behavior. Additional support and advice should be provided and promoted for isolated people. Engaging in social networks from a remote location and maintaining a routine is likely to reduce the negative effects of isolation for wellness (Content et al., 2020).

Positive behavioral feedback involves interest in complying with regulatory measures in all three countries. In all three countries, acceptance of avoidance behavior, recommended behavior measures and information sufficiency was similar, and trust in government was similar in Singapore and Italy. Respondents in both Singapore and China were more willing to wear masks (Singapore 85.8\%; China mean score 4.78 [range: 1-5]) (Lim et al., 2020); as similar as these three countries Bangladeshi people have a higher level of trust in government.

Developing countries (e.g., Bangladesh) facing a variety of challenges to deploy these. It is almost difficult to change behaviors (Zhaia \& Du, 2020). Over reactive behavior was common among the general public that can impede infection control (Dong \& Bouey, 2020). As a Public Health Emergency a large population is either not aware or has no access to the information provided (Khan, et al., 2020). COVID-19 pandemic is fear. This can lead to individuals committing suicide (Cullen et al., 2020) although suicidal cases were happened in Bangladesh due to COVID-19. People with pre-existing (perceived danger, fear of virus transmission, social isolation, uncertainty, physical discomfort, and overwhelming negative news in mass media (D, et al., 2020) will be at increased risk of infection and negative physical effect with COVID-19. Serious mortality, rapid transmission and higher morbidity (Khan, et al., 2020) also increase this. The sudden increase in confirmed cases has brought tremendous anxiety and that can affect perception, behavior (PAKPOUR \& GRIFFITHS, 2020). Anxiety is a state that results from an individual's perception and behaviors to those stressors. Moreover anxiety may vary by gender, age. According to our study, there was a difference between genders in perception; females were more concerned about corona virus. Recommend behaviors conducting and awareness to improve self confidence (Xu et al., 2020) is important for this pandemic. The use of instant-messaging technology and mobile phones, media has a negative effect, although government increases companying for control misinformation (Xu et al., 2020).These negative emotions can protect from disease but negative emotions can reduce the immune function and physiological mechanisms ( (Zhou et al., 2020). Social and cultural factors, immediacy, uncertainty, familiarity, personal control, scientific uncertainty, and trust in institutions and media all shape perception and response to risk messaging is one of the risk of COVID-19.Risk messaging can influence the everchanging public behavior (Malecki et al., 2020) like maintaining hand hygiene and social distancing to prevent its spread. But in Bangladesh strictly adhere to the restrictions. Public adherence to government recommended protective behavior is crucial to the control of the spread of coronavirus (Duan et al., 2020). The psychological process may influence individual protective behavior, government intervention and perception, with the making trust to the adoption of protective behavior (Duan et al., 2020).

\section{Conclusion}

Coronavirus can reduce the incidence of a number of potential behavioral (recommended and avoided) diseases: closing major events, closing schools, using public transportation, using masks, disinfecting items, isolating the marked person, and their Family, general social distance and long social distance for people at risk. Public opinion and support for this; probably loyalty; And any barriers, facilitators or communication issues may be considered. There can be several common problems across these behavioral interventions. To increase confidence and loyalty to the intervention, the government should: provide clear and unambiguous reasons for strategies that have been chosen or not chosen; Reduce ambiguity wherever possible; and conduct quick research on how to help people follow their advice. Specific ideas about each intervention should be provided. These may be aimed at bridging common social distances and involving higher levels of public support, and the isolation of significant cases has the potential to 
create intuitive knowledge for many people which becomes detrimental challenges. Possible challenges include high levels of social barriers, mental, and physical problems after school closures, including public gatherings and restrictions on economic and other practical issues. Elements that can extend loyalty, including increased risk perception, improved government communication, remote support for isolation, and encouraging support from the community, can mitigate challenges. The government needs to provide clear advice on how to reduce risk-taking behaviors that take into account public concerns. Transparency will help people understand risks and build confidence. Treating people with respect enables them to make their own decisions and manage personal risks.

\section{References}

1. Asmundson, G. J., \& Taylor, S. (2020). How health anxiety influences responses to viral outbreaks like COVID-19: What all decision-makers, health authorities, and health care professionals need to know. Journal of Anxiety Disorders, 71. doi:https://doi.org/10.1016/j.janxdis.2020.102211

2. Balkhi, F., Nasir, A., Zehra, A., \& Riaz, R. (2020). Psychological and Behavioral Response to the Coronavirus (COVID-19) Pandemic. Cureus, 12(5), e7923. doi:10.7759/cureus.7923

3. Bao, Y., Sun, Y., Meng, S., Shi, J., \& Lu, L. (2020). 2019-nCoV epidemic:address mental health care to empower society. The Lancet, 395, e38. doi:https://doi.org/10.1016/S0140-6736(20)30309-3

4. Bavel, J. J., Baicker, K., \& Willer, ]. (2020). Using social and behavioural science to support COVID-19 pandemic response. Nature Human Behaviour volume, 4, 460-471. doi:https://doi.org/10.1038/s41562-020-0884-z

5. Bhagavathula, A. S., Aldhaleei, W. A., Rahmani, J., Mahabadi, M. A., \& Bandari, D. K. (2020). Knowledge and Perceptions of COVID-19 Among Health Care Workers: Cross-Sectional Study. JMIR Public Health Surveill, 6(2), e19160. doi:DOI: $10.2196 / 19160$

6. Content, M. A., Belton, C. A., Lavin, C., McGowan, F. P., Timmons, S., \& Robertson, D. A. (2020). Using Behavioral Science to help fight the Coronavirus. Journal of Behavioral Public Administration, 3(1). doi:https://doi.org/10.30636/jbpa.31.147

7. Cullen, W., Gulati, G., \& Kelly, B. D. (2020). Mental health in the Covid-19 pandemic. QJM, hcca110. doi:doi: 10.1093/qjmed/hcaa110

8. D, T., V, S., M, C., G, C., S, F., E, T., . . F, P. (2020). Mental health outcomes of the CoViD-19 pandemic. Rivista di Psichiatria, 55(3), 137-144. doi:DOI: 10.1708/3382.33569

9. Dhaka Tribune. (2020, May 20). Policeman reportedly commits suicide over coronavirus stigma. Dhaka, Dhaka, Bangladesh. Retrieved from https://www.dhakatribune.com/health/coronavirus/2020/05/04/tested-negative-sb-constable-commits-suicideafter-facing-social-stigma

10. Dong, L., \& Bouey, J. (2020). Public Mental Health Crisis during COVID-19 Pandemic, China. Emerging Infectious Diseases, 26(7), 1616-1618. doi:https://dx.doi.org/10.3201/eid2607.200407

11. Dong, Y., Mo, X., Hu, Y., Qi, X., Jiang, F., Jiang, Z., \& Tong, S. (2020). Epidemiological Characteristics of 2143 Pediatric Patients With 2019 Coronavirus Disease in China. Pediatrics. doi:10.1542/peds.2020-0702

12. Duan, T., Jiang, H., Deng, X., Zhang, Q., \& Wang, F. (2020). Government Intervention, Risk Perception, and the Adoption of Protective Action Recommendations: Evidence from the COVID-19 Prevention and Control Experience of China. Int $J$ Environ Res Public Health, 17(10), 3387. doi:doi: 10.3390/ijerph17103387

13. Dutheil, F., Mondillon, L., \& Navel, V. (2020). PTSD as the Second Tsunami of the SARS-Cov-2 Pandemic. Psychological Medicine, 1-2. doi:https://doi.org/10.1017/S0033291720001336

14. Ho, C. S., Chee, C. Y., \& Ho, R. C. (2020). Mental Health Strategies to Combat the Psychological Impact of Coronavirus. Annals, Academy of Medicine, 49, 155-160. doi:PMID: 32200399

15. Institute of Epidemiology, Disease Control and Research. (2020, September 11). Official Updates Coronavirus - COVID-19 in Bangladesh. Retrieved September 11, 2020, from Institute of Epidemiology, Disease Control and Research: https://corona.gov.bd/? gclid=Cj0KCQjwwOz6BRCgARIsAKEG4FX1CVqQEtAhIL7Mg3WBLCOE9tGQ10k3ayyEZuTgp1ZDWQIGNDJJqIYaArNPEALw_wcB

16. Khan, S., Siddique, R., Li, H., Ali, A., Shereen, M. A., Bashir, N., \& Xue, M. (2020). Impact of coronavirus outbreak on psychological health. J Glob Health, 10(1), 010331. doi:doi: 10.7189/jogh.10.010331 
17. Lim, J. M., Tun, Z. M., Kumar, V., Quaye, S. E., Offeddu, V., Cook, A. R., .. Tam, C. C. (2020). Population anxiety and positive behaviour change during the COVID-19 epidemic: Cross-sectional surveys in Singapore, China and Italy. Wiley. doi: https://doi.org/10.1111/irv.12785

18. Malecki, K. M., Keating, I. A., \& Safdar, s. (2020). Crisis Communication and Public Perception of COVID-19 Risk in the Era of Social Media. Clinical Infectious Diseases, ciaa759. doi:https://doi.org/10.1093/cid/ciaa758

19. Marteau, T. M., \& Bekker, H. (1992). The development of a six-item short-form of the state scale of the Spielberger State-Trait Anxiety Inventory (STAI). British Journal of Clinical Psychology, 31(3), 301-306. doi:https://doi.org/10.1111/j.20448260.1992.tb00997

20. PAKPOUR, A. H., \& GRIFFITHS, M. D. (2020). The fear of COVID-19 and its role in preventive behaviors. Journal of Concurrent Disorders. Retrieved from http://irep.ntu.ac.uk/id/eprint/39561/1/1313636_Griffiths.pdf

21. The British Psychological Society. (2020). Behavioural science and disease prevention:Psychological guidance. Retrieved from The British Psychological Society: https://www.bps.org.uk/sites/www.bps.org.uk/files/Policy/Policy\%20-

\%20Files/Behavioural\%20science\%20and\%20disease\%20prevention\%20-

\%20Psychological\%20guidance\%20for\%20optimising\%20policies\%20and\%20communication.pdf

22. Uzun, S., Vural, H., Uzun, M., \& Yokusoglu, M. (2008). State and trait anxiety levels before coronary angiography. J Clin Nurs, 17(5), 602-607. doi:10.1111/j.1365-2702.2007.02018.x

23. Wang, C., Pan, R., Wan, X., Tan, Y., Xu, L., Ho, C. S., \& Ho, R. C. (2020). Immediate Psychological Responses and Associated Factors during the Initial Stage of the 2019 Coronavirus Disease (COVID-19) Epidemic among the General Population in China. Int J Environ Res Public Health, 17(5), 1729. doi:10.3390/ijerph17051729

24. West, R., Michie, S., Rubin, G. J., \& Amlôt, R. (2020). Applying principles of behaviour change to reduce SARS-CoV-2 transmission. Nature Human Behaviour, 4, 451-459. doi:https://doi.org/10.1038/s41562-020-0887-9

25. World Health Organization . (2020, August 25). COVID-19 Bangladesh situation reports-14. Retrieved August 27, 2020, from World Health Organization : http//:www.world health organization

26. World Health Organization. (2020, January 1). 2019-nCoV outbreak is an emergency of international concern. Retrieved from World Health Organization

27. https://www.euro.who.int/en/health-topics/health-emergencies/coronavirus-covid-19/news/news/2020/01/2019-ncovoutbreak-is-an-emergency-of-international-concern

28. World Health organization. (2020, March 11). WHO Director-General's opening remarks at the media briefing on COVID-19. Retrieved from World Health organization: https://www.who.int/dg/speeches/detail/who-director-general-s-opening-remarks-atthe-media-briefing-on-covid-19--11-march-2020

29. Xiang, Y.-T., Yang, Y., Li, W., Zhang, L., Zhang, Q., Cheung, T., \& Ng, C. H. (2020). Timely mental health care for the 2019 novel coronavirus outbreak is urgently needed. The Lancet, 7(3). doi:DOI:https://doi.org/10.1016/S2215-0366(20)30046-8

30. Xu, J., Xu, Q.-h., Wang, C.-m., \& Wang, J. (2020). Psychological status of surgical staff during the COVID-19 outbreak. Psychiatry Res., 288, 112955. doi:10.1016/j.psychres.2020.112955

31. Xu, Z., Li, S., Tian, S., Li, H., \& Kong, L.-q. (2020). Full spectrum of COVID-19 severity still being depicted. The Lancet, $395,947$. doi:https://doi.org/10.1016/S0140-6736(20)30308-1

32. Zhaia, Y., \& Du, X. (2020). Addressing collegiate mental health amid COVID-19 pandemic. Psychiatry Res., 288, 113003. doi: 10.1016/j.psychres.2020.113003

33. Zhou, X., Snoswell, C. L., Harding, L. E., Bambling, M., Edirippulige, S., Bai, X., \& Smith, A. C. (2020). The Role of Telehealth in Reducing the Mental Health Burden from COVID-19. Telemedicine and e-Health, 26(4), 377-379. doi:10.1089/tmj.2020.0068

\section{Tables}

Table 1: Behavioral responses to corona virus outbreak 
Questions

No (\%) of positive responses

"Over the past four days, I have ... because of coronavirus":

Deliberately cancelled or postponed a social event, such as meeting friends, eating out, or going to a $\quad 3200(50 \%)$ sports event*

Reduced the amount I use transport*

$1792(28 \%)$

Taken time off work*

$3456(54 \%)$

Reduced the amount I go into shops*

$2688(42 \%)$

Kept one or more of my children out of home*

$1664(26 \%)$

Kept away from crowded places generally*

$1664(26 \%)$

Increased the amount I clean or disinfect things that I might touch $\dagger$

$3072(48 \%)$

Washed my hands with soap and water more often than usualt

$2944(46 \%)$

Because of coronavirus, I have discussed with a friend or family member what we would do if one of

$1920(30 \%)$

us catches coronavirust

Performed $\geq 1$ of the three recommended behaviours

$4096(64 \%)$

Performed $\geq 1$ of the six avoidance behaviours

$3840(60 \%)$

*Behavioural changes classified as avoidance.

†Behavioural changes classified as recommended.

Table 2: Perceived efficacy of various behavioral responses regarding to coronavirus. Values are numbers (percentages) of participants

\begin{tabular}{|c|c|c|c|c|c|}
\hline Questions & $\begin{array}{l}\text { Strongly } \\
\text { agree }\end{array}$ & $\begin{array}{l}\text { Tend to } \\
\text { agree }\end{array}$ & $\begin{array}{l}\text { Neither agree nor } \\
\text { disagree }\end{array}$ & $\begin{array}{l}\text { Tend to } \\
\text { disagree }\end{array}$ & $\begin{array}{l}\text { Strongly } \\
\text { disagree }\end{array}$ \\
\hline \multicolumn{6}{|l|}{$\begin{array}{l}\text { I believe that ... reduces your risk of catching } \\
\text { corona virus: }\end{array}$} \\
\hline $\begin{array}{l}\text { Reducing the number of people you meet } \\
\text { over a day }\end{array}$ & $1664(26 \%)$ & $896(14 \%)$ & $1408(22 \%)$ & $1024(16 \%)$ & $1408(22 \%)$ \\
\hline Avoiding transport (spacing at start) & $3200(50 \%)$ & $896(14 \%)$ & $512(8 \%)$ & $896(14 \%)$ & $896(14 \%)$ \\
\hline $\begin{array}{l}\text { Cleaning or disinfecting things you might } \\
\text { touch }\end{array}$ & $1920(30 \%)$ & $1024(16 \%)$ & $768(12 \%)$ & $1024(16 \%)$ & $1664(26 \%)$ \\
\hline Avoiding hospitals or general practices & $896(14 \%)$ & $1152(18 \%)$ & $896(14 \%)$ & $1024(16 \%)$ & $2432(38 \%)$ \\
\hline Wearing a face mask when out in public & $2560(40 \%)$ & $896(14 \%)$ & $1152(18 \%)$ & $768(12 \%)$ & $1024(16 \%)$ \\
\hline $\begin{array}{l}\text { Washing your hands regularly with soap and } \\
\text { water }\end{array}$ & $1792(28 \%)$ & $768(12 \%)$ & $896(14 \%)$ & $768(12 \%)$ & $2176(34 \%)$ \\
\hline
\end{tabular}

Table 3: Association between personal variables and behavior during corona virus outbreak 


\begin{tabular}{|c|c|c|c|c|c|c|c|}
\hline \multirow[t]{2}{*}{ Variable } & \multirow[t]{2}{*}{$\begin{array}{l}\text { No }(\%) \text { of } \\
\text { participants }\end{array}$} & \multicolumn{3}{|c|}{$\begin{array}{l}\text { using more than one avoidance } \\
\text { behaviors' }\end{array}$} & \multicolumn{3}{|c|}{$\begin{array}{l}\text { using more than one recommended } \\
\text { behaviors' }\end{array}$} \\
\hline & & Prevalence & OR $(95 \% \mathrm{Cl})$ & $\begin{array}{l}\mathrm{aOR}(95 \% \\
\mathrm{Cl})\end{array}$ & Prevalence & $\begin{array}{l}\mathrm{OR}(95 \% \\
\mathrm{Cl})\end{array}$ & $\begin{array}{l}\mathrm{aOR}(95 \% \\
\mathrm{Cl})\end{array}$ \\
\hline \multicolumn{8}{|l|}{ Gender } \\
\hline Male & 3456 & 2176 & 1 & 1 & 2304 & 1 & 1 \\
\hline Female & 2944 & 1664 & $\begin{array}{l}1.31(1.83- \\
1.45)\end{array}$ & $\begin{array}{l}1.57(1.4- \\
1.8)\end{array}$ & 1792 & $\begin{array}{l}1.29(1.2- \\
1.4)\end{array}$ & $\begin{array}{l}1.26(1.13- \\
1.4)\end{array}$ \\
\hline \multicolumn{8}{|l|}{ Age } \\
\hline 18 to 30 & 896 & 512 & $\begin{array}{l}1.31(1.11- \\
1.56)\end{array}$ & $.66(.54-.82)$ & 512 & $.63(.53-.74)$ & $.8(.66-.98)$ \\
\hline 30 to 40 & 2176 & 1408 & $.96(.83-1.1)$ & $1.1(.91-1.3)$ & 2048 & $.05(.04-.06)$ & $.04(.03-.05)$ \\
\hline 40 to 50 & 1920 & 1024 & 1.5(1.3-1.8) & $\begin{array}{l}1.5(1.3- \\
1.81)\end{array}$ & 896 & $.95(.83-1.1)$ & $\begin{array}{l}1.96(1.7- \\
2.3)\end{array}$ \\
\hline $50+$ & 1408 & 896 & 1 & 1 & 640 & 1 & 1 \\
\hline \multicolumn{8}{|c|}{ Income( Bangladeshi currency) } \\
\hline bellow 20000 & 1152 & 512 & $\begin{array}{l}1.25(1.08- \\
1.45)\end{array}$ & $\begin{array}{l}1.39(1.18- \\
1.65)\end{array}$ & 640 & $\begin{array}{l}1.08(.92- \\
1.24)\end{array}$ & $\begin{array}{l}1.11(.94- \\
1.31)\end{array}$ \\
\hline 20000 to 50000 & 2304 & 1664 & $.38(.34-.44)$ & $.57(.5-.66)$ & 1408 & $.85(.75-.96)$ & $.81(.71-.93)$ \\
\hline 50000 to 70000 & 1152 & 768 & $.5(.43-.58)$ & $\begin{array}{l}.89(.74- \\
1.06)\end{array}$ & 1024 & $.17(.14-.21)$ & $.2(.16-.25)$ \\
\hline $70000+$ & 1792 & 896 & 1 & 1 & 1024 & 1 & 1 \\
\hline \multicolumn{8}{|l|}{ chronic illness } \\
\hline No & 3968 & 2048 & 1 & 1 & 2304 & 1 & 1 \\
\hline Yes & 2432 & 1792 & $\begin{array}{l}2.63(2.35- \\
2.93)\end{array}$ & $\begin{array}{l}3.41(3.03- \\
3.84)\end{array}$ & 1792 & $\begin{array}{l}2.02(1.81- \\
2.26)\end{array}$ & $\begin{array}{l}1.97(1.75- \\
2.21)\end{array}$ \\
\hline \multicolumn{8}{|l|}{ Region } \\
\hline City & 3200 & 1792 & $\begin{array}{l}1.4(1.26- \\
1.54)\end{array}$ & $\begin{array}{l}2.36(2.1- \\
2.66)\end{array}$ & 2176 & $.71(.64-.78)$ & $\begin{array}{l}.92(.82- \\
1.04)\end{array}$ \\
\hline village & 3200 & 2048 & 1 & 1 & 1920 & 1 & 1 \\
\hline \multicolumn{8}{|l|}{ Education level } \\
\hline below grade 12 & 2688 & 1280 & $\begin{array}{l}2.44(2.21- \\
2.71)\end{array}$ & $\begin{array}{l}3.86(3.42- \\
4.36)\end{array}$ & 1792 & $.82(.74-.91)$ & $.88(.78-.98)$ \\
\hline $\begin{array}{l}\text { more than } \\
\text { grade } 12\end{array}$ & 3712 & 2560 & 1 & 1 & 2304 & 1 & 1 \\
\hline
\end{tabular}

Table 4: Association between perception variables and behavior during corona virus outbreak 


\begin{tabular}{|c|c|c|c|c|c|}
\hline \multirow[t]{2}{*}{ Perception factors } & \multirow[t]{2}{*}{$\begin{array}{l}\text { mean } \\
\text { score }\end{array}$} & \multicolumn{2}{|c|}{$\begin{array}{l}\text { using more than one avoidance } \\
\text { behaviors' }\end{array}$} & \multicolumn{2}{|c|}{$\begin{array}{l}\text { using more than one recommended } \\
\text { behaviors' }\end{array}$} \\
\hline & & OR $(95 \% \mathrm{Cl})$ & *aOR $(95 \% \mathrm{Cl})$ & OR $(95 \% \mathrm{Cl})$ & *aOR $(95 \% \mathrm{Cl})$ \\
\hline Trust in government & 2.08 & $2.32(2.07-2.61)$ & $1.64(1.4-1.91)$ & $1.90(1.72-2.1)$ & $1.9(1.72-2.1)$ \\
\hline $\begin{array}{l}\text { Likelihood of } \\
\text { infection }\end{array}$ & 1.92 & $2.33(2.06-2.63)$ & $2.32(2.1-2.63)$ & $1.56(1.4-1.75)$ & $1.6(1.4-1.75)$ \\
\hline Severity of illness & 1.58 & $2.04(1.9-2.2)$ & $2.04(1.9-2.2)$ & $1.56(1.46-1.67)$ & $1.6(1.46-1.7)$ \\
\hline Exaggeration of risk & 1.58 & $1.22(1.15-1.29)$ & $1.22(1.2-1.3)$ & $1.11(1.05-1.18)$ & $1.1(1.05-1.2)$ \\
\hline Timeline of outbreak & 1.84 & $1.19(1.12-1.25)$ & $1.19(1.1-1.25)$ & $1.2(1.14-1.27)$ & $1.2(1.14-1.3)$ \\
\hline \multicolumn{6}{|c|}{$\begin{array}{l}\text { Scores from } 1 \text { to } 5 \text {. High scores indicate greater agreement that: the authorities are to be trusted in handling corona virus; I am at } \\
\text { risk of catching corona virus; corona virus is a severe illness; the outbreak has been over-exaggerated; the outbreak will continue } \\
\text { for some time; }\end{array}$} \\
\hline
\end{tabular}

